\title{
Pre-milking mechanical teat stimulation and milking performance of dairy buffaloes in early lactation
}

\author{
Francesco Maria Tangorra, ${ }^{1}$ Stefania Leonardi, ${ }^{1}$ Valerio Bronzo, ${ }^{2}$ Nicola Rota, ${ }^{2}$ Paolo Moroni ${ }^{2,3}$ \\ ${ }^{1}$ Department of Health, Animal Science and Food Safety, University of Milano, Italy; ${ }^{2}$ Department of Veterinary \\ Medicine, University of Milano, Italy; ${ }^{3}$ Animal Health Diagnostic Center, Quality Milk Production Services, Cornell \\ University, Ithaca, NY, USA
}

\begin{abstract}
The objective of the present study was to investigate the effect of pre-milking mechanical teat stimulation on milk yield and milking performance of dairy buffaloes in early lactation. For this purpose, twenty-two healthy Italian Mediterranean buffaloes in their first to third lactation and in early lactation $(<120$ days in milk) were subjected to two treatments of teat stimulation: i) washing of the teats with water for about $5 \mathrm{~s}$ and attaching of the milking unit within $60 \mathrm{~s}$, without any pre-milking massage (farm milking routine); ii) fast pulsation (FP), achieved by increasing pulsation rate to 120 pulsations per min during the first $60 \mathrm{~s}$ after application of teat cups. Each treatment lasted for 10 days and the following parameters were measured: milk yield (kg/milking), milk yield at 2 min after unit attachment $(\mathrm{kg})$, time between milking unit attachment and its automatic removal (min), peak milk flow rate $(\mathrm{kg} / \mathrm{min})$, and milking time to reach peak flow rate ( $\mathrm{min})$. The average milk flow rate $(\mathrm{kg} / \mathrm{min})$ was calculated by dividing milk yield by the actual milking time. Milk yield was not affected by mechanical pre-stimulation and during the first 2 min of milking $20.2 \%$ and $19.6 \%$ of total milk yield were milked respectively when treatments 1 and 2 were applied. The time elapsed from attachment of the milking cluster until its automatic removal was less than $8 \mathrm{~min}$ both for buffaloes subjected to FP, and for buffaloes subjected just to washing of the teats before attaching the milking unit. FP stimulation did not show an enhancing effect on
\end{abstract}

Correspondence: Francesco Maria Tangorra, Department of Health, Animal Science and Food Safety (VESPA), University of Milano, via Celoria 10, 20133 Milano, Italy.

Tel.: +39.02.50317904.

E-mail: francesco.tangorra@unimi.it

Key words: Fast pulsation; milking performance; dairy buffalo.

Received for publication: 27 September 2016.

Accepted for publication: 26 November 2016.

(C) Copyright F.M. Tangorra et al., 2017

Licensee PAGEPress, Italy

Journal of Agricultural Engineering 2017; XLVIII:606

doi:10.4081/jae.2017.606

This article is distributed under the terms of the Creative Commons Attribution Noncommercial License (by-nc 4.0) which permits any noncommercial use, distribution, and reproduction in any medium, provided the original author(s) and source are credited. peak and average milk flow rates and on milking time to reach peak flow rate.

\section{Introduction}

Mechanised milking is commonly used today in buffalo farms. Reducing the labour cost, improving the management and the productivity of farms, and increasing the hygiene of milk are the key factors for machine milking of dairy buffaloes (Ambord et al., 2010; Caria et al., 2011). At the present time, the technology and the milking machine settings usually adopted for dairy buffaloes come from dairy cows, although some morphological and physiological differences between the two species exist (Thomas et al., 2005; Caria et al., 2011).

The milk cisternal fraction in dairy buffaloes is smaller than in dairy cows (about 5\% vs 20\%) and frequently it is not immediately available for the milking machine as in dairy cows (Thomas et al., 2005), so teats are exposed to the vacuum without milk flow for a long time. Due to their slow milk ejection reflex and their thicker sphincter muscle around the streak canal in comparison with dairy cows, dairy buffaloes are known to be slow and hard to milk: lag time before milk let-down ranges from 1.6 to $6.3 \mathrm{~min}$ (Thomas et al., 2005; Bava et al., 2007; Caria et al., 2011). As in dairy cows, milk ejection in dairy buffaloes occurs in response to oxytocin release, which is induced primarily by teat stimulation (Bruckmaier, 2005; Thomas et al., 2005). The application of an attachment delay of 60-90 s after stimulation before milking is recommended to ensure immediate and continuous milk flow after the start of milking in dairy cows (Rasmussen et al., 1992). Thomas et al. (2005) found that milk ejection in Indian Murrah buffaloes occurred significantly earlier for machine milking with in-parlour feeding and 1-min manual pre-stimulation (washing, drying and short massage of teats) than for machine milking without manual pre-stimulation or in-parlour feeding. This highlighted that a careful teat preparation and pre-stimulation are important preconditions for successful milk removal also in dairy buffaloes.

Ambord et al. (2010) confirmed this finding in Mediterranean buffaloes. In their study, the time until milk ejection and the incidence of delayed milk ejection decreased with increasing duration of manual pre-stimulation (teats and udder cleaning with a wet cotton towel and teats drying with single-use paper before cluster attachment) up to $3 \mathrm{~min}$. After a 3 -min pre-stimulation the milk flow occurred immediately after cluster attachment without interruptions until the end of milking.

Proper pre-milking manual stimulation is a time consuming chore that may affect the milking parlour throughput, reducing the number of cows milked per hour per person (Sagi et al., 1980). 
Teat stimulation through the action of the milking machine is an alternative to manual stimulation. The effectiveness of mechanical pre-stimulation in eliciting milk ejection in dairy cows was investigated by several authors between the end of the 1970's and the beginning of 1980's (Thompson and Blouin, 1978; Sagi et al., 1980). More recently, Weiss and Bruckmaier (2005) investigated the oxytocin release and various milking characteristics (milk yield, stripping yield, total machine-on time, main milking time, peak flow rate, and main milk flow rate) in dairy cows after the application of various pre-stimulation routines by vibration stimulation lasting between 0 and $90 \mathrm{~s}$. To our knowledge, the teat stimulation through the action of the milking machine has not yet been studied in dairy buffaloes.

The objective of the present study was to investigate the effect of pre-milking mechanical stimulation of teats on milk yield and milking performance of dairy buffaloes in early lactation.

\section{Materials and methods}

\section{Animals and husbandry}

Twenty-two healthy Italian Mediterranean buffaloes were used in this study. They were selected from a private farm in Northern Italy (Lombardia) with 300 lactating buffaloes. In this farm parity ranged from 1 to 8 lactations and the animals were housed into two different barns according to their lactation stage: buffaloes in the early lactation at $<120$ days in milking (DIM) were housed in a loose-housing barn, while buffaloes in mid and late lactation $(>120$ DIM) were kept in a mat-lined free stalls barn. Total mixed ration was fed once a day according to lactation stage.

Milking took place daily at 4 a.m. and 4 p.m. in a $2 \times 14$ herringbone-milking parlour with a low-level pipeline milking system (TDM, Manerbio, Italy). Milking units equipped with Californiastyle claws (Coburn, Whitewater, WI, USA) and liners 0243/1000 (Spaggiari, Luzzara, Italy) were used. The working parameters were $40.5 \mathrm{kPa}$ vacuum, 60 cycles $/ \mathrm{min}$ pulsator rate, and $60 \%$ pulsator ratio. The automatic cluster removers were set up to detach the milking unit when the milk flow was lower than $100 \mathrm{~g} / \mathrm{min}$. No concentrate feed was administered to the animals during milking.

\section{Experimental design}

Buffaloes involved in the experiment $(n=22)$ were in their first to third lactation, and they were in early lactation at $<120$ DIM. They were assigned randomly to two treatments of teat stimulation in a crossover design: i) washing of the teats with water for about $5 \mathrm{~s}$ and attaching of the milking unit within $60 \mathrm{~s}$, without any premilking massage. That was the milking routine usually performed at the farm; ii) fast pulsation (FP), achieved by increasing pulsation rate to 120 pulsations per min at a working vacuum of $40.5 \mathrm{kPa}$ during the first $60 \mathrm{~s}$ after application of teat cups. This pulsation frequency is similar to that generated by calf during suckling (Thompson and Blouin, 1978). To avoid additional stimulatory effects, the teats were not cleaned, fore-stripped or touched before teat cups were attached. Therefore, the duration of the pre-milking stimulation by fast pulsation was exactly the time between the first contact of the liner to the teats and the start of milking pulsation.

The duration of the experiment was 20 days with each treatment lasting 10 days (the first 3 days representing an adaptation time for the animals, and the last 7 days the data collecting period). Data were collected at the two daily milkings and included the following milking variables measured with the AfiFarm herd management software (v. 3.06, Afimilk ${ }^{\mathrm{TM}}$, S.A.E. AFIKIM, Israel): milk yield ( $\mathrm{kg} /$ milking), milk yield during first 2 min after unit attachment $(\mathrm{kg})$, actual milking time, i.e., time elapsed from attachment of the milking cluster until its automatic removal (min), peak milk flow rate $(\mathrm{kg} / \mathrm{min})$, and milking time to reach peak flow rate $(\mathrm{min})$. The average milk flow rate $(\mathrm{kg} / \mathrm{min})$ was calculated by dividing milk yield by the actual milking time.

\section{Data selection and statistical analysis}

Before analysis, data from nine buffaloes that repeatedly kicked at the milking units leading to clusters falling off and incomplete milkings or had radio frequency identification problems when entering the milking stalls were discarded. As a consequence, a total of 364 milking records from 13 buffaloes (four in first lactation, five in second, and four in third lactation) were used in the present study.

For statistical analysis, the SAS ${ }^{\circledR} 9.2$ statistical package (SAS Institute Inc., Cary, NC, USA, 2009) was used. Treatment effects were tested for significance $(\mathrm{P}<0.05)$ using the MIXED procedure in SAS.

The model used was the following:

$\mathrm{Y}_{\mathrm{ijklm}}=\mu+\mathrm{T}_{\mathrm{i}}+\mathrm{D}_{\mathrm{j}}+\mathrm{Ti}_{\mathrm{k}}+\mathrm{L}_{\mathrm{l}}+$ Buffalo $_{\mathrm{m}}\left(\mathrm{T}_{\mathrm{i}}\right)+\mathrm{e}_{\mathrm{ijklm}}$

where: $Y_{\mathrm{ijklm}}=$ milk yield $(\mathrm{kg} / \mathrm{milking})$, or milk yield at $2 \mathrm{~min}(\mathrm{~kg})$, or milking time ( $\mathrm{min}$ ), or milking time to reach peak flow rate (min), or peak flow rate $(\mathrm{kg} / \mathrm{min})$, or average flow rate $(\mathrm{kg} / \mathrm{min}) ; \mu$ $=$ overall mean; $\mathrm{T}_{\mathrm{i}}=$ effect of pre-milking treatment $(\mathrm{i}=1$ to 2 , washing of the teats - fast pulsation); $\mathrm{D}_{\mathrm{j}}=$ effect of day of milking ( $\mathrm{j}=$ date of milking); $\mathrm{Ti}_{\mathrm{k}}=$ effect of time of milking $(\mathrm{k}=1$ to 2 , morning - evening); $\mathrm{L}_{1}=$ effect of lactation number $(1=1$ to 3 ); Buffalo $_{\mathrm{m}}\left(\mathrm{T}_{\mathrm{i}}\right)=$ effect of buffalo [ $\mathrm{m}=1$ to13] within the treatment; and $\mathrm{e}_{\mathrm{ijk} k \mathrm{~m}}=$ random error with zero mean and variance. Results are presented as least square means.

Table 1. Least square means for milking variables (total number of observations per variable $=364$ ).

\begin{tabular}{|c|c|c|c|c|}
\hline & & & & \\
\hline & Washing of the teats & FP stimulation & Pooled SEM & $\mathbf{P}$ \\
\hline Milk yield (kg/milking) & 5.35 & 5.30 & 0.14 & NS* \\
\hline Milk yield at 2 min (kg) & 1.08 & 1.04 & 0.10 & NS \\
\hline Actual milking time (min) & 7.89 & 7.62 & 0.16 & NS \\
\hline Peak flow rate (kg/min) & 1.73 & 1.71 & 0.07 & NS \\
\hline Milking time to reach peak flow rate (min) & 3.20 & 3.10 & 0.14 & NS \\
\hline Avg. flow rate (kg/min) & 0.69 & 0.74 & 0.02 & NS \\
\hline
\end{tabular}

FP, fast pulsation; SEM, standard error of the mean; Avg., average. ${ }^{*}$ Not significant, $P>0.05$. 


\section{Results and discussion}

Least square means of treatments for milking variables are reported in Table 1. Milk yield was not affected by mechanical prestimulation as reported in previous studies on dairy cows (Sagi et al., 1980; Weiss and Bruckmaier, 2005). Milk yield per milking was consistent with the stage of lactation and comparable with data recorded by Bava et al. (2007) in a study on Mediterranean Italian buffaloes milked without any udder preparation before milking. Caria et al. (2014), in a study aimed to evaluate the performance of the first automatic milking system (AMS) for buffaloes, recorded a lower milk yield per milking in comparison with the value found in our experiment when FP was applied $(2.8 \mathrm{~kg} / \mathrm{milking} v s 5.3$ $\mathrm{kg} /$ milking). Although in the AMS each teat is individually cleaned, pre-milked and dried before milking, which represents de facto a pre-stimulation, the difference found in milk yields per milking could be mainly due to the different characteristics (lactation stage and parity) of animals involved in the two studies.

During the first 2 min of milking $20.2 \%$ and $19.6 \%$ of total milk yield was harvested respectively when treatments 1 and 2 were applied. Both values are lower than those reported by Caria et al. (2012), even if the operating conditions were different. In that study the milk yield at 2 min from buffaloes subjected to manual teat stimulation and milking cluster attachment after $60 \mathrm{~s}$ represented $37.3 \%$ of the total milk extracted a $37 \mathrm{kPa}$ and $60.9 \%$ at $52 \mathrm{kPa}$.

FP stimulation did not influence the actual milking time. In dairy cows Sagi et al. (1980) reported a longer machine-on time when teat stimulation was performed increasing pulsation rate and changing pulsation ratio (7.0 $\mathrm{min})$, in comparison with manual (6.0 $\mathrm{min}$ ) and no stimulation (6.5 $\mathrm{min})$. In our experiment the time elapsed from attachment of the milking cluster until its automatic removal was less than 8 min both for buffaloes subjected to fast pulsation, and for buffaloes subjected just to washing of the teats before attaching the milking unit. This value is markedly lower if compared with manual removal of the teat cups (Thomas et al., 2005; Bava et al., 2007; Caria et al., 2011), confirming that the operator's choice to not use automatic cluster removers, as frequently occurs in dairy buffaloes milking, strongly influences the milking time. In buffaloes milked by AMS the milking duration averaged $8.3 \pm 2.7 \mathrm{~min}$ (Caria et al., 2014), even if in that case it was calculated as the time between the buffalo identification and the last teat-cup detachment.

FP stimulation did not show an enhancing effect on peak and average milk flow rates and on milking time to reach peak flow rate, as previously observed by Sagi et al. (1980) in dairy cows. On the contrary, Weiss and Bruckmaier (2005) found that peak and average flow rates were both improved with increasing duration $(0-90 \mathrm{~s})$ of mechanical pre-stimulation in dairy cows when udders were not full, whereas peak and average flow rates did not differ with increasing stimulation in full udders. The average milk flow rate calculated in buffaloes milked by AMS (Caria et al., 2014) was higher than that recorded in the present study when FP was applied $(1.3 \mathrm{~kg} / \mathrm{min} v s 0.7 \mathrm{~kg} / \mathrm{min})$, suggesting a positive effect of the pre-milking stimulation executed by the AMS on milk flow rate and machine on time.

\section{Conclusions}

In conclusion, fast pulsation, achieved by increasing pulsation rate to 120 pulsations per min during the first $60 \mathrm{~s}$ after application of teat cups, does not seem to have an enhancing effect on milking performances of dairy buffaloes in early lactation. Further attempts should be to measure responses of milk flow rate to various modes of mechanical udder stimulation (e.g., increasing pulsation rates and changing pulsation ratios during a certain time after application of teat cups and under different vacuum conditions) throughout a lactational cycle of buffaloes.

\section{References}

Ambord S., Stoffel M.H., Bruckmaier R.M. 2010. Teat anatomy affects requirements for udder preparation in Mediterranean buffaloes. J. Dairy Res. 77:468-73.

Bava L., Sandrucci A., Tamburini A., Zucali M. 2007. Milk flow traits of buffalo cows in intensive farming system. Ital. J. Anim. Sci. 6:500-2.

Caria M., Boselli C., Murgia L., Rosati R., Pazzona A. 2012. Effect of vacuum level on milk flow traits in Mediterranean Italian buffalo cow. Ital. J. Anim. Sci. 11:137-9.

Caria M., Murgia L., Pazzona A. 2011. Effects of the working vacuum level on mechanical milking of buffalo. J. Dairy Sci. 94:1755-61.

Caria M., Tangorra F.M., Leonardi S., Bronzo V., Murgia L., Pazzona A. 2014. Evaluation of the performance of the first automatic milking system for buffaloes. J. Dairy Sci. 97:1491-8.

Rasmussen M.D., Frimer E.S., Galton D.M. 1992. The influence of pre-milking teat preparation and attachment delay on milk yield and milking. J. Dairy Sci. 75:2131-41.

Sagi R., Gorewit R.C., Zinn S.A. 1980. Milk ejection in cows mechanically stimulated during late lactation. J. Dairy Sci. 63:1957-60.

Thomas C.S., Bruckmaier R.M., Ostensson K., SvennerstenSjaunja K. 2005. Effect of different milking routines on milking-related release of the hormones oxytocin, prolactin and cortisol, and on milk yield and milking performance in Murrah buffaloes. J. Dairy Res. 72:10-8.

Thompson P.D., Blouin M.S. 1978. Stimulation of the milk ejection reflex by positive pressure pulsation, water spray or hand washing. J. Dairy Sci. 61:135.

Weiss D., Bruckmaier R.M. 2005. Optimisation of individual prestimulation in dairy cows. J. Dairy Sci. 88:137-47. 